\title{
MTOR Variation Related to Heat Resistance of Chinese Cattle
}

\author{
Qingqing Ning ${ }^{1}$, Kaixing $\mathrm{Qu}^{2}$, Quratulain Hanif ${ }^{3}{ }^{\mathbb{D}}$, Yutang Jia ${ }^{4}$, Haijian Cheng ${ }^{5}$, Jicai Zhang ${ }^{2}$, \\ Ningbo Chen ${ }^{1}$, Hong Chen ${ }^{1}$, Bizhi Huang ${ }^{2, *}$ and Chuzhao Lei ${ }^{1, *} \mathbb{C}$ \\ 1 Key Laboratory of Animal Genetics, Breeding and Reproduction of Shaanxi Province, College of Animal \\ Science and Technology, Northwest A\&F University, Yangling 712100, China; 18392375865@139.com (Q.N.); \\ ningboch@126.com (N.C.); chenhong1212@263.net (H.C.) \\ 2 Yunnan Academy of Grassland and Animal Science, Kunming 650212, China; kaixqu@163.com (K.Q.); \\ ynzjc@126.com (J.Z.) \\ 3 National Institute for Biotechnology and Genetic Engineering, Pakistan Institute of Engineering and Applied \\ Sciences, Faisalabad 577, Pakistan; micro32uvas@gmail.com \\ 4 Institute of Animal Science and Veterinary Medicine, Anhui Academy of Agriculture Science, Hefei 230001, \\ China; yutang2018@163.com \\ 5 Institute of Animal Science and Veterinary Medicine, Shandong Academy of Agricultural Sciences, \\ Jinan 250100, China; 98061107@163.com \\ * $\quad$ Correspondence: hbz@ynbp.cn (B.H.); leichuzhao1118@126.com (C.L.); Tel.: +86-135-7299-2159 (C.L.)
}

Received: 16 October 2019; Accepted: 29 October 2019; Published: 4 November 2019

check for updates

Simple Summary: Due to unique geographical distribution and appearance characteristics, China cattle has been divided into three groups: northern cattle (dominated by Bos taurus in northern China), central cattle (admixture of Bos taurus and Bos indicus in the middle region) and southern cattle (dominated by Bos indicus in southern China). With this rule, it was believed that southern in cattle are more heat resistant than northern cattle. Previous studies showed that the mechanistic target of the rapamycin (MTOR) (NC_037343.1:c.2062G>C) gene could be associated with heat resistance. This study used PCR and sequencing to type this locus in 1030 individuals of 37 cattle breeds and proved the mutation of this locus could be related to heat tolerance in Chinese cattle.

Abstract: With the inexorable rise of global temperature, heat stress deserves more and more attention in livestock agriculture. Previous studies have shown that the mechanistic target of rapamycin (MTOR) (NC_037343.1:c.2062G>C) gene contributes to the repair of DNA damage repair and is associated with the adaptation of camels in dry and hot environments. However, it is unknown whether this mutation is related to the heat tolerance of Chinese cattle. In this study, PCR and sequencing were used to type the mutation locus in 1030 individuals of 37 cattle breeds. The analysis results showed that the frequency of $\mathrm{G}$ allele of the locus gradually diminished from the northern group to the southern group of native Chinese cattle, whereas the frequency of the $\mathrm{C}$ allele showed an opposite pattern, displaying a significant geographical difference across native Chinese cattle breeds. Additionally, an analysis of the locus in Chinese indigenous cattle revealed that this SNP was significantly associated with mean annual temperature $(\mathrm{T})$, relative humidity $(\mathrm{RH})$ and temperature humidity index (THI) $(p<0.01)$, suggesting that cattle with $C$ allele was distributed in regions with higher T, RH and THI. In conclusion, this study proved that the mutation of MTOR gene in Chinese cattle could be associated with the heat tolerance.

Keywords: Chinese cattle; MTOR gene; variation; heat tolerance; association 


\section{Introduction}

Environments of high temperatures and humidity are detrimental to the productivity of commercial animal agriculture [1,2]. Therefore, in this case, heat stress in cattle negatively impacts on animal production, impairs normal bodily function, jeopardizes animal welfare [3-7] and also causes massive livestock economy losses [5]. However, the detrimental effects of HS (heat stress) will likely become more serious if the earth's climate continues to warm as predicted [8].

The indiscriminate emission of greenhouse gases not only causes global warming but also destroys the ozone layer and leads to increasing ultraviolet radiation. Based on previous research, mammalian cells exposed to environmental stresses require an efficient DNA repair mechanism to maintain genomic instability [9]. Coincidently, the mechanistic target of rapamycin (MTOR) has roles related to DNA damage repair, and its mechanism has been confirmed by many studies. Dominick et al. (2017) proved that a novel link between DNA repair and mTOR signaling via post-transcriptional regulation and mRNA level involving specific alteration in the CCR4-NOT complex, which means if CCR4-NOT complex as downstream of MTOR gene in regulating NDRG1 (N-myc downstream-regulated gene 1) and MGMT (O-6-methylguanine-DNA methyltransferase) expression is reduced or inactivated, it will lead to improve DNA repair capacity [10,11]. Reiter et al. (2004) reported that mTOR can also regulate stress resistance by preferential translation of certain mRNAs [12]. Furthermore, this gene has been identified as the rapidly evolving genes in camels, which results in insulin resistance via serine phosphorylation of insulin receptor substrates proteins to store energy and hold a high-level blood glucose. Further, this is conducive to survive in hot and arid deserts or semi-deserts [13,14].

In line with the above studies regarding heat resistance, the related gene located in 16 chromosome (NC_037343.1) about Bos taurus was found by the National Center for Biotechnology Information (NCBI). In the meantime, this study went on to search for a SNP (mutation frequency over 0.2, rs445599276) located in $\sim 1.1 \mathrm{~kb}$ downstream of the MTOR gene from the Bovine Genome Variation Database and Selective Signatures (BGVD) [15], and more importantly whose allele frequency distribution of Chinese cattle breeds were significant geographical distribution rules (such as Dianzhong (6):0.750 in southern China but Chaidamu (5):0.000 and Tibetan (9):0.000 in northern China). Taken together, it has a selective advantage to speculate that the MTOR mutation might be linked to the thermo-tolerance.

China is one of the countries with the most abundant livestock and poultry genetic resources in the world, containing more than 53 cattle breeds [16]. China's geographical address is located across the cold temperate, temperate and subtropical zone, which contributes to different temperature and humidity from north to south. Therefore, due to its unique geographical distribution and appearance characteristics, it is divided into three groups: northern cattle (dominated by Bos taurus in northern China), central cattle (admixture of Bos taurus and Bos indicus in the middle region) and southern cattle (dominated by Bos indicus in southern China) [17]. Additionally, as a new generation of molecular genetic markers, SNPs are of great value for the animals' genetic diversity and structure, origin, phenotypic correlation analysis and so forth [18].

From the above, Chinese cattle breeds are very suitable for the detection of SNP in the bovine MTOR gene and for testing the relationship between MTOR variants and the mean annual temperature $(\mathrm{T})$, relative humidity $(\mathrm{RH})$ and the temperature humidity index (THI) of a sampling site. It is expected that results of this study will provide basic data for marker-assisted selection related to the heat tolerance.

\section{Materials and Methods}

\subsection{Ethics Statement}

The protocols used in this study for the animals were recognized by the Faculty Animal Policy and Welfare Committee of the Northwest A\&F University (FAPWC-NWAFU, protocol number, NWAFAC1008). 


\subsection{Animal Samples Information, DNA Extraction, and Data Collection}

The genomic DNA of 1030 individuals representing 35 Chinese native cattle breeds as well as Angus and Burmese cattle as controls (Supplementary Table S1) was extracted from ear tissue samples using standard phenol-chloroform method [19]. The controls were identified relatively as pure Bos taurus and Bos indicus according to previous studies which proved: Bos indicus possessed the best heat resistance [20], whereas Bos taurus did not have thermal mutations at all [21,22]. Then, the extracted genomic DNA concentration was determined by spectrophotometry, correspondingly diluted to $10 \mathrm{ng} / \mu \mathrm{L}$ and finally, stored at $-80{ }^{\circ} \mathrm{C}$ until use.

Three environmental parameters (T, RH, THI) at the sampling sites of 35 native cattle breeds in the past 30 years (from 1971 to 2000) were collected by the Chinese Central Meteorological Agency (http://data.cma.cn/) (Table S1).

\subsection{Primers Information, PCR Amplification and PCR Product Processing}

The primers of MTOR gene locus were designed through NCBI and used to type this SNP. The primer sequences, fragment sizes and annealing temperatures are shown in Supplementary Table S2. Each $25 \mu \mathrm{L}$ PCR amplification mixture contained $20 \mathrm{ng}$ of genomic DNA, $20 \mathrm{pmol} / \mu \mathrm{L}$ of each primer, $0.2 \mathrm{mmol}$ of dNTPs, $1 \times$ PCR buffer (including $2.5 \mathrm{mmol}$ of $\mathrm{Mg}^{2+}$ ) and $1.0 \mathrm{U}$ of rTaq DNA polymerase (Takara, Dalian, China). A thermocycling protocol was $5 \mathrm{~min}$ at $95^{\circ} \mathrm{C}$ and 35 cycles of $94{ }^{\circ} \mathrm{C}$ for $30 \mathrm{~s}$, annealing at $54{ }^{\circ} \mathrm{C}$ for $30 \mathrm{~s}$ and at $72{ }^{\circ} \mathrm{C}$ for $30 \mathrm{~s}$ (Table S2), with a final extension at $72{ }^{\circ} \mathrm{C}$ for $10 \mathrm{~min}$. The PCR products of all 1030 samples were detected by electrophoresis on a $2.0 \%$ agarose gel stained with ethidium bromide. Then, PCR products were directly sequenced with an ABI PRIZM 377 DNA sequencer (PerkinElmer). All tests were conducted at Shanghai Sangon Biotech Company, Shanghai, China. The sequencing results were read by Chromas 2.6.5 Software (Technelysium Pty Ltd., South Brisbane, Queensland, Australia).

\subsection{Statistic Analysis of MTOR Gene Polymorphism}

According to the Hardy-Weinberg equilibrium (HWE), the genotypic and allele frequencies were calculated directly based on the genotypes observed in the analyzed breeds. Then, the allele frequency of each breed would be depicted on the map of China by a pie chart in order to observe its distribution in Chinese cattle (Figure 1). The PowerMarker v3.25 software (North Carolina State University, Raleigh, NC, USA) was used to calculate and analyze the allele frequencies, alleles per locus (Ne), observed heterozygosity (Ho) and Nei's expected heterozygosity (He) for the MTOR locus [23]. Then, the Hardy-Weinberg balance was tested by the program POPGENE Version 1.31 (University of Calgary, Calgary, AB, Canada) [24,25]. The polymorphism was measured by the polymorphism information content (PIC) value for the MTOR locus [26].

The Hardy-Weinberg equilibrium (HWE) formula as follows:

$$
p+q=1 \text { and } p^{2}+2 \times p \times q+q^{2}=1
$$

The G allele frequency of MTOR gene is $\mathrm{p}$. The C allele frequency of MTOR gene is $\mathrm{q}$.

$$
\begin{gathered}
\mathrm{H}_{0}=\sum_{\mathrm{i}=1}^{\mathrm{n}} \mathrm{P}_{\mathrm{i}}^{2} \mathrm{H}_{\mathrm{e}}=1-\sum_{\mathrm{i}=1}^{\mathrm{n}} \mathrm{P}_{\mathrm{i}}^{2} \mathrm{Ne}=1 / \sum_{\mathrm{i}=1}^{\mathrm{n}} \mathrm{P}_{\mathrm{i}}^{2} \\
\mathrm{PIC}=1-\sum_{\mathrm{i}=1}^{\mathrm{m}} \mathrm{P}_{\mathrm{i}}^{2}-\sum_{\mathrm{i}=1}^{\mathrm{m}-1} \sum_{\mathrm{j}=\mathrm{i}+1}^{\mathrm{m}} 2 \mathrm{P}_{\mathrm{i}}^{2} \mathrm{P}_{\mathrm{j}}^{2}
\end{gathered}
$$

In our study, THI was calculated based on the formula used by the National Oceanic and Atmospheric Administration (1976) [27]:

$$
\mathrm{THI}=(1.8 \mathrm{~T}+32)-(0.55-0.0055 \mathrm{RH}) \times(1.8 \mathrm{~T}-26)
$$


where $\mathrm{T}$ is temperature in degrees Celsius and $\mathrm{RH}$ is relative humidity as a percentage.

The least square means (LSM) of the distribution of the three environmental parameters (T, RH, THI) of the 35 Chinese cattle breeds were calculated using a general linear model using a IBM SPSS Modeler 23.0 Software (SPSS, Inc., Armonk, NY, USA):

$$
Y_{i}=\mu+G_{i}+B_{i}+e_{i}
$$

where $Y_{i}$ is the value of T, RH and THI between 1971 and 2000, $\mu$ is the overall mean value, $G_{i}$ is the fixed genotype effect, $B_{i}$ is the fixed effect of breeds and $e_{i}$ is a random residual effect. The differences were considered significant at $p<0.05$.

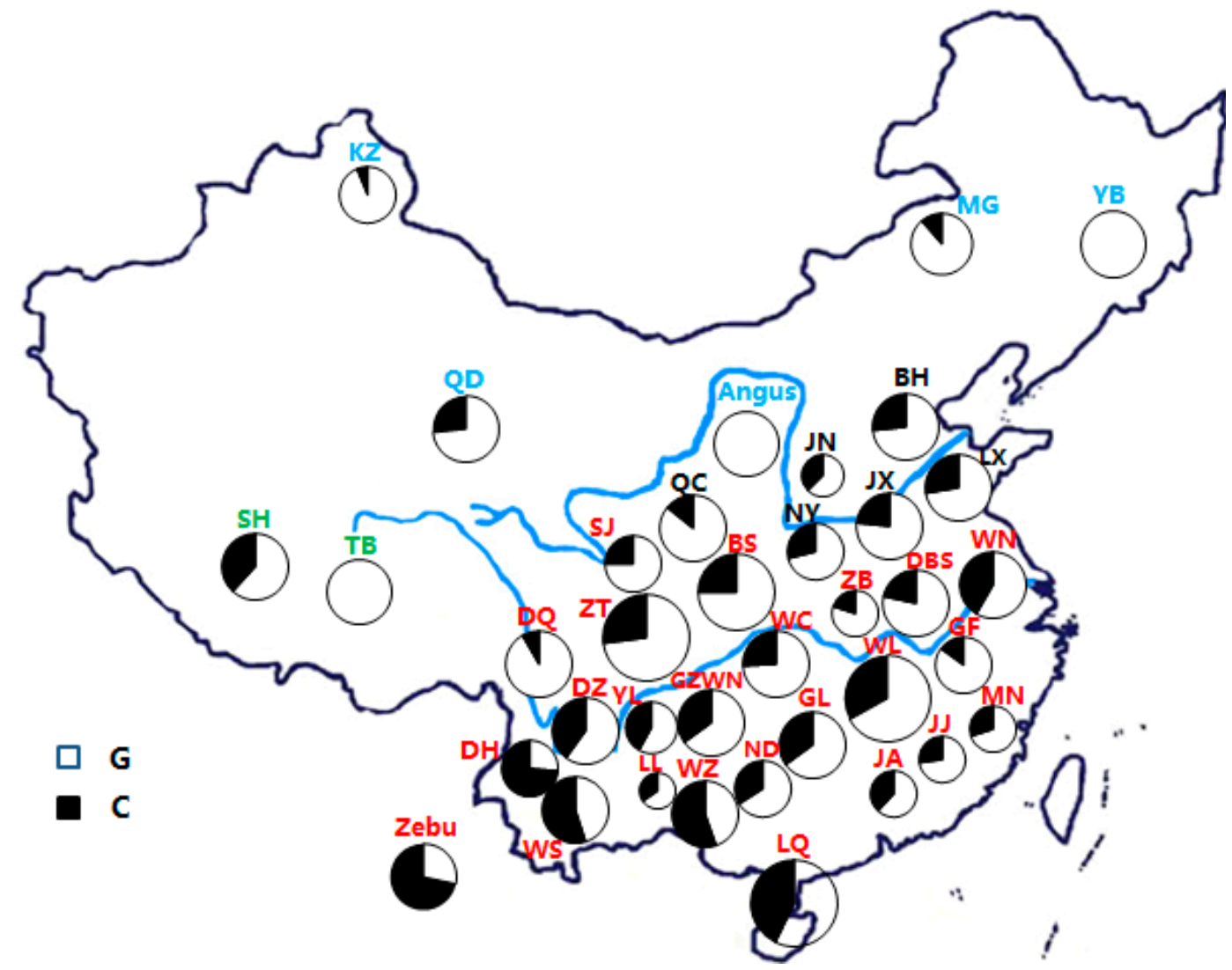

Figure 1. (a) Geographical distribution of two variants among 35 Chinese breeds as well as Augus and Burma populations. (b) Distribution of G and C alleles of the NC_037343.1:c.2062G>C loci of the MTOR gene. (c) YB, Yanbian; MG, Mongolian; KZ, Kazakh; QD, Chaidamu; SH, Shigatse Humped; TB Tibetan; BH, Bohai Black; JN, Jinnan; JX, Jiaxian Red; QC, Qinchuan; LX, Luxi; NY, Nanyang; WN, Wannan; DBS, Dabieshan; ZB, Zaobei; BS, Bashan; WC, Wuchuan; SJ, Sanjiang; ZT, Zhaotong; DQ, Diqing; DZ, Dianzhong; YL, Yunling; GZWN, Weining; GL, Guanling; GF, Guangfeng; MN, Minnan; JJ Jinjiang; JA, Ji'an; LQ, Leiqiong; WZ, Weizhou; ND, Nandan; LL, Longlin; DH, Dehong; WS, Wenshan; WL, Wuling.

\section{Results}

\subsection{Diversity Analysis}

The $\mathrm{H}_{0}, \mathrm{H}_{\mathrm{e}}, \mathrm{N}_{\mathrm{e}}$ and PIC of 37 breeds cattle in MTOR (NC_037343.1:c.2062G $>$ C) locus were calculated by the relevant formulas (Table 1). From our research, $\mathrm{H}_{0}$ was detected from 0.5050 to 1.000 and $\mathrm{H}_{\mathrm{e}}$ was from 0.0783 to 0.4950 , which meant that they were not subject to high intensity selection and had rich genetic diversity [28]. According to the site polymorphism criteria determined by Botstein, there were twenty-nine loci which were reasonable polymorphism $(0.5>$ PIC $>0.25)$, eight were only slight polymorphism (PIC $<0.25$ ) and no one had high polymorphism (PIC $>0.5$ ). 
Furthermore, both of the moderate and low polymorphisms were distributed in the northern, central and southern populations. From the results of the test of the Hardy-Weinberg equilibrium for genetic diversity, the genotypic frequencies of GG, GC and CC were respectively $51.34 \%, 37.53 \%$ and $11.13 \%$, and the results of the $\chi^{2}$ test indicated that there were only three breeds (Yanbian, Tibetan and Angus) having significant differences $(p<0.05)$, indicating that other 34 breeds all reached the genetic balance $(p>0.05)$.

Table 1. Genetic indices $p$-value, $\mathrm{Ho}, \mathrm{He}, \mathrm{Ne}$ and polymorphism information content (PIC) of the MTOR gene across 35 Chinese cattle breeds as well as Angus and Burma.

\begin{tabular}{|c|c|c|c|c|c|}
\hline Breeds & $p$-Value & Ho & $\mathrm{He}$ & $\mathrm{Ne}$ & PIC \\
\hline Kazakh (KZ) & 0.0625 & 0.8830 & 0.1170 & 1.1330 & 0.1103 \\
\hline Yanbian (YB) & 0.0000 & 1.0000 & 0.0000 & 1.0000 & 0.0000 \\
\hline Chaidamu (QD) & 0.2667 & 0.6089 & 0.3911 & 1.6423 & 0.3146 \\
\hline Mongolian (MG) & 0.1143 & 0.7976 & 0.2024 & 1.2538 & 0.1820 \\
\hline Jiaxian Red (JX) & 0.2333 & 0.6422 & 0.3578 & 1.5571 & 0.2938 \\
\hline Nanyang (NY) & 0.2895 & 0.5886 & 0.4114 & 1.6988 & 0.3267 \\
\hline Luxi (LX) & 0.2759 & 0.6005 & 0.3995 & 1.6653 & 0.3197 \\
\hline Bohai Black (BH) & 0.2667 & 0.6089 & 0.3911 & 1.6423 & 0.3146 \\
\hline Jinnan (JN) & 0.3750 & 0.5313 & 0.4688 & 1.8824 & 0.3589 \\
\hline Qinchuan (QC) & 0.1429 & 0.7551 & 0.2449 & 1.3243 & 0.2149 \\
\hline $\mathrm{Ji}^{\prime}$ an $(\mathrm{JA})$ & 0.3824 & 0.5277 & 0.4723 & 1.8951 & 0.3608 \\
\hline Jinjiang (JJ) & 0.2727 & 0.6033 & 0.3967 & 1.6575 & 0.3180 \\
\hline Wannan (WN) & 0.4167 & 0.5139 & 0.4861 & 1.9459 & 0.3680 \\
\hline Weining (GZWN) & 0.3500 & 0.5450 & 0.4550 & 1.8349 & 0.3515 \\
\hline Zaobei (ZB) & 0.2000 & 0.6800 & 0.3200 & 1.4706 & 0.2688 \\
\hline Dabeishan (DBS) & 0.2167 & 0.6606 & 0.3394 & 1.5139 & 0.2818 \\
\hline Bashan (BS) & 0.2500 & 0.6250 & 0.3750 & 1.6000 & 0.3047 \\
\hline Leiqiong (LQ) & 0.4286 & 0.5102 & 0.4898 & 1.9600 & 0.3698 \\
\hline Wengshan (WS) & 0.5500 & 0.5050 & 0.4950 & 1.9802 & 0.3725 \\
\hline Dianzhong (DZ) & 0.6000 & 0.5200 & 0.4800 & 1.9231 & 0.3648 \\
\hline Guangfeng (GF) & 0.1500 & 0.7450 & 0.2550 & 1.3423 & 0.2225 \\
\hline Sanjiang (SJ) & 0.2500 & 0.6250 & 0.3750 & 1.6000 & 0.3047 \\
\hline Wuling (WL) & 0.3308 & 0.5573 & 0.4427 & 1.7944 & 0.3447 \\
\hline Guanling (GL) & 0.3500 & 0.5450 & 0.4550 & 1.8349 & 0.3515 \\
\hline Wuchuan (WC) & 0.2586 & 0.6165 & 0.3835 & 1.6220 & 0.3099 \\
\hline Minnan (MN) & 0.3000 & 0.5800 & 0.4200 & 1.7241 & 0.3318 \\
\hline Longling (LL) & 0.3462 & 0.5473 & 0.4527 & 1.8270 & 0.3502 \\
\hline Weizhou (WZ) & 0.5536 & 0.5057 & 0.4943 & 1.9773 & 0.3721 \\
\hline Nandan (ND) & 0.3400 & 0.5512 & 0.4488 & 1.8142 & 0.3481 \\
\hline Diqing (DQ) & 0.0833 & 0.8472 & 0.1528 & 1.1803 & 0.1411 \\
\hline Yunnan Humped (DH) & 0.7368 & 0.6122 & 0.3878 & 1.6335 & 0.3126 \\
\hline Zhaotong (ZT) & 0.2708 & 0.6050 & 0.3950 & 1.6528 & 0.3170 \\
\hline Yunling (YL) & 0.4200 & 0.5128 & 0.4872 & 1.9501 & 0.3685 \\
\hline Tibetan (TB) & 0.0000 & 1.0000 & 0.0000 & 1.0000 & 0.0000 \\
\hline Shigatse Humped (SH) & 0.3833 & 0.5272 & 0.4728 & 1.8967 & 0.3610 \\
\hline Burma (MD) & 0.7167 & 0.5939 & 0.4061 & 1.6838 & 0.3236 \\
\hline Angus (AG) & 0.0000 & 1.0000 & 0.0000 & 1.0000 & 0.0000 \\
\hline
\end{tabular}

\subsection{Statistical Analysis of Genotypic and Allele Frequencies}

The Angus and Burmese cattle were used as the controls to determine the allele frequencies for the $B$. taurus and $B$. indicus cattle populations. The allele frequency was obtained by counting genotype frequencies (Table 2 and Figure 1). The results showed that the $\mathrm{C}$ allele frequency of MTOR gene reached $71.67 \%$ in the Burma population, whereas all Angus cattle carried the G allele (Table 2 and Figure 1). 
Table 2. Genotypic and allele frequencies of the MTOR genes across 37 cattle breeds.

\begin{tabular}{|c|c|c|c|c|c|c|c|}
\hline \multirow{3}{*}{$\begin{array}{l}\text { Geographical } \\
\text { Grouping }\end{array}$} & \multirow{3}{*}{ Breeds (Codes) } & \multicolumn{5}{|c|}{ MTOR (NC_037343.1:c. 2062G>C) } & \multirow{3}{*}{$\begin{array}{c}\text { Mutation } \\
\text { Frequencies }\end{array}$} \\
\hline & & \multicolumn{3}{|c|}{ Genotype Frequencies (Number) } & \multicolumn{2}{|c|}{ Allele Frequencies } & \\
\hline & & GG & GC & $\mathrm{CC}$ & G & $\mathrm{C}$ & \\
\hline \multirow{3}{*}{$\begin{array}{l}\text { Northern } \\
\text { group }\end{array}$} & Kazakh (KZ) & $0.08750(21)$ & $0.1250(3)$ & $0.0000(0)$ & 0.9375 & 0.0625 & 0.0625 \\
\hline & Yanbian (YB) & $1.0000(30)$ & $0.0000(0)$ & $0.0000(0)$ & 1.0000 & 0.0000 & 0.0000 \\
\hline & Chaidamu (QD) & $0.5333(16)$ & $0.4000(12)$ & $0.0667(2)$ & 0.7333 & 0.2667 & 0.2667 \\
\hline \multirow{5}{*}{ Central group } & Jiaxian Red (JX) & $0.5667(17)$ & $0.4000(12)$ & $0.0333(1)$ & 0.7667 & 0.2333 & 0.2333 \\
\hline & Nanyang (NY) & $0.4737(9)$ & $0.4737(9)$ & $0.0526(1)$ & 0.7105 & 0.2895 & 0.2895 \\
\hline & Luxi (LX) & $0.5172(15)$ & $0.4138(12)$ & $0.0690(2)$ & 0.7241 & 0.2759 & 0.2759 \\
\hline & Bohai Black (BH) & $0.6000(18)$ & $0.2667(8)$ & $0.1333(4)$ & 0.7333 & 0.2667 & 0.2667 \\
\hline & Jinnan (JN) & $0.5000(6)$ & $0.2500(3)$ & $0.2500(3)$ & 0.6250 & 0.3750 & 0.3750 \\
\hline \multirow{16}{*}{$\begin{array}{l}\text { Southern } \\
\text { group }\end{array}$} & Jinjiang (JJ) & $0.4545(5)$ & $0.5454(6)$ & $0.0000(0)$ & 0.7273 & 0.2727 & 0.2727 \\
\hline & Wannan (WN) & $0.3333(10)$ & $0.5000(15)$ & $0.1667(5)$ & 0.5833 & 0.4167 & 0.4167 \\
\hline & Weining (GZWN) & $0.3667(11)$ & $0.5667(17)$ & $0.0667(2)$ & 0.6500 & 0.3500 & 0.3500 \\
\hline & Zaobei (ZB) & $0.6000(6)$ & $0.4000(4)$ & $0.0000(0)$ & 0.8000 & 0.2000 & 0.2000 \\
\hline & Dabeishan (DBS) & $0.6333(19)$ & $0.3000(9)$ & $0.0667(2)$ & 0.7833 & 0.2167 & 0.2167 \\
\hline & Bashan (BS) & $0.5227(23)$ & $0.4545(20)$ & $0.0227(1)$ & 0.7500 & 0.2500 & 0.2500 \\
\hline & Leiqiong (LQ) & $0.3061(15)$ & $0.5306(26)$ & $0.1633(8)$ & 0.5714 & 0.4286 & 0.4286 \\
\hline & Wengshan (WS) & $0.1000(3)$ & $0.7000(21)$ & $0.2000(6)$ & 0.4107 & 0.5893 & 0.5893 \\
\hline & Dianzhong (DZ) & $0.1333(4)$ & $0.5333(16)$ & $0.3333(10)$ & 0.4000 & 0.6000 & 0.6000 \\
\hline & Guangfeng (GF) & $0.7000(7)$ & $0.3000(3)$ & $0.0000(0)$ & 0.8500 & 0.1500 & 0.3000 \\
\hline & Sanjiang (SJ) & $0.5385(14)$ & $0.4231(11)$ & $0.0385(1)$ & 0.7500 & 0.2500 & 0.2500 \\
\hline & Wuling (WL) & $0.4923(32)$ & $0.3538(23)$ & $0.1538(10)$ & 0.6692 & 0.3308 & 0.3308 \\
\hline & Yunnan Humped (DH) & $0.0000(0)$ & $0.5263(10)$ & $0.4737(9)$ & 0.2632 & 0.7368 & 0.7368 \\
\hline & Zhaotong $(\mathrm{ZT})$ & $0.5625(27)$ & $0.3333(16)$ & $0.1042(5)$ & 0.7292 & 0.2708 & 0.2708 \\
\hline & Yunling (YL) & $0.2800(7)$ & $0.6000(15)$ & $0.1200(3)$ & 0.5800 & 0.4200 & 0.4200 \\
\hline & & $0.4283(275)$ & $0.4330(278)$ & $0.1386(89)$ & 0.6449 & 0.3551 & 0.3551 \\
\hline \multirow{3}{*}{ Special } & Tibetan (TB) & $1.0000(29)$ & $0.0000(0)$ & $0.0000(0)$ & 1.0000 & 0.0000 & 0.0000 \\
\hline & Shigatse Humped (SH) & $0.40000(12)$ & $0.4333(13)$ & $0.1667(5)$ & 0.6167 & 0.3833 & 0.3833 \\
\hline & & $0.6949(41)$ & $0.2203(13)$ & $0.0848(5)$ & 0.8051 & 0.1949 & 0.1949 \\
\hline \multirow{3}{*}{ Exotic } & Over all & $0.5134(498)$ & $0.3753(364)$ & $0.1113(108)$ & 0.7010 & 0.2990 & 0.2990 \\
\hline & Burma (MD) & $0.0667(2)$ & $0.4333(13)$ & $0.5000(15)$ & 0.2833 & 0.7167 & 0.7167 \\
\hline & Angus (AG) & $1.0000(30)$ & $0.0000(0)$ & $0.0000(0)$ & 1.0000 & 0.0000 & 0.0000 \\
\hline
\end{tabular}

A base transversion (NC_037343.1:c.2062G>C) mutation was detected in the MTOR gene. This study then explored the allelic and genotypic frequencies of the locus in Chinese cattle, as shown in Table 2. At the MTOR: c.2062G>C locus, three genotypes (GG, GC and CC) were detected and the mean allelic frequencies for the $G$ allele and $C$ allele in Chinese cattle were $70.10 \%$ and $29.90 \%$, respectively. In terms of the detailed geographic distribution, the frequencies of the $C$ allele for the northern, central and southern groups were $0.1134,0.2500$ and 0.3551 respectively, and were gradually diminishing in the Chinese indigenous cattle from south to north.

\subsection{Correlation Analysis of MTOR Gene Polymorphism}

The results of the association analysis by one-way ANOVA between the genotypes and the three environmental parameters ( $\mathrm{T}, \mathrm{RH}$ and THI) for 35 breeds in 970 Chinese indigenous cattle were shown in Table S1. At the MTOR: c.2062G>C locus, there was a significant association between the allele $\mathrm{C}$ and $\mathrm{T}, \mathrm{RH}$ and THI. The individuals with CC or GC genotypes were found in areas with significantly higher 
T, RH and THI values compared with those having the GG genotype $(p<0.01)$ (Figure 1$)$, suggesting that the allele $\mathrm{C}$ might be associated with heat tolerance in Chinese indigenous cattle. The test of effects of the three study parameters on MTOR genotype showed that the mean annual temperature had the strongest correlation with the genotypes (Table 3 and Supplementary Table S3).

Table 3. Association of the MTOR gene variation with temperature (T), relative humidity $(\mathrm{RH})$ and the temperature humidity index (THI) in Chinese cattle.

\begin{tabular}{|c|c|c|c|c|}
\hline SNP & Genotype (n) & $\mathrm{T}\left({ }^{\circ} \mathrm{C}\right)(\mathrm{LSM} \pm \mathrm{SE})$ & $\mathrm{RH}(\%)(\mathrm{LSM} \pm \mathrm{SE})$ & $\mathrm{THI}(\mathrm{LSM} \pm \mathrm{SE})$ \\
\hline \multirow{3}{*}{$\begin{array}{c}\text { MTOR } \\
\text { :NC_037343.1:c.2062G >C }\end{array}$} & CC(108) & $16.06^{\mathrm{A}} \pm 0.54$ & $74.43^{\mathrm{A}} \pm 0.99$ & $60.19^{\mathrm{A}} \pm 0.76$ \\
\hline & GC(364) & $15.12^{\mathrm{A}} \pm 0.29$ & $72.89^{\mathrm{A}} \pm 0.59$ & $59.07^{\mathrm{A}} \pm 0.41$ \\
\hline & GG(498) & $12.05^{\mathrm{B}} \pm 0.25$ & $68.53^{\mathrm{B}} \pm 0.49$ & $54.60^{\mathrm{B}} \pm 0.35$ \\
\hline
\end{tabular}

$\mathrm{LSM} \pm \mathrm{SE}$, least squares means and their standard errors for each genotypic class reported. Uppercase letters mean differences of the value at $p<0.01$. SNP, the single nucleotide polymorphism; T, the mean annual temperature; $\mathrm{RH}$, the relative humidity; THI, the temperature humidity index.

\section{Discussion}

In recent years, the frequency of thermal diseases in animals has risen with the increase of the global temperature. Previous studies reported that the heat illness, a continuum of disorders caused by hyperthermia, includes heat cramps, heat exhaustion, heat injury and heat stroke [29-31], and the systemic inflammatory response syndrome (SIRS) is considered to be the primary cause of organ dysfunction related to heat stroke [32,33]. Therefore, the selection of heat-resistant traits is necessary in the commercial cattle industry. Additionally, previous study results also showed that the rapidly evolving MTOR gene for camels plays an important role in adapting the dryness-heat environment [13]. Furthermore, the MTOR gene had been proved to repair DNA damage via post-transcriptional regulation and the mRNA level involving specific alteration in the CCR4-NOT complex (located in the downstream of the mTORC1 pathway), which regulates N-myc downstream-regulated gene 1 and O-6-methylguanine-DNA methyltransferase to effect the DNA damage repair [10-12]. The MTOR gene was just exact for the cattle to maintain genomic instability when exposed to excessive ambient temperature. Therefore, we speculated that MTOR was an important candidate gene responsible for heat tolerance in Chinese cattle.

Furthermore, the distribution of allelic frequencies in the control groups showed that the allele $\mathrm{G}$ of the MTOR gene is dominant in B.taurus cattle (Angus), whereas the $C$ allele is dominant in $B$. indicus cattle (Burmese zebu). A similar pattern was observed in the Chinese native cattle population. The results also showed that the frequencies of $G$ allele of the MTOR gene diminished gradually in native Chinese cattle from the northern group to the southern group, whereas the frequencies of the $C$ allele showed an opposite pattern (Figure 1), indicating a significant geographical difference across native Chinese cattle breeds and consistent with the distribution of indicine and taurine cattle in China. For the southern group, the highest frequencies of the $\mathrm{C}$ allele of the MTOR gene were found in cattle in southwestern China, which has the highest temperatures compared to other regions, followed by cattle in southeastern China. Correspondingly, this study also found that cattle breeds with particularly high $\mathrm{C}$ allele frequency had higher mean annual temperatures in the southern region. The results were consistent with previous studies that revealed the geographical environment and origin of Chinese indigenous cattle $[21,22,34,35]$.

\section{Conclusions}

In conclusion, the results indicated that the variant of the MTOR gene was associated with heat tolerance in Chinese cattle and could be used in the marker-assisted selection program to improve the heat tolerance trait of Chinese cattle.

Supplementary Materials: The following are available online at http://www.mdpi.com/2076-2615/9/11/915/s1. Additional supporting information may be found online in the supporting information section at the end 
of the article. Supplementay Table S1 Distribution of 35 cattle breeds of China as well as Angus and zebu populations; Supplementay Table S2 Primer sequences and fragment size for PCR amplification of the MTOR gene; Supplementay Table S3 Test of three subjects' effects on MTOR genotypes.

Author Contributions: Conceptualization: Q.N. and C.L.; methodology: H.C.; validation: Q.N. and C.L.; formal analysis: N.C. and J.Z.; investigation: K.Q., Q.H., Y.J., and J.Z.; resources: B.H. and C.L.; data curation: Y.J. and H.C.; writing—original draft preparation: Q.N. and C.L.; writing—review and editing: H.C., Q.H., and C.L.; visualization: K.Q.; supervision: N.C.; project administration: Q.N., B.H and C.L.; funding acquisition: B.H. and C.L.

Funding: This work was supported by the Program of National Beef Cattle and Yak Industrial Technology System (No. CARS-37), the Program of Yunling Scholar and the Young and Middle-aged Academic Technology Leader Backup Talent Cultivation Program in Yunnan Province, China (No. 2018HB045), Yunnan Provincial Major S\&T Project (2019ZG007).

Conflicts of Interest: The authors declare that they have no conflict of interest to this work.

\section{References}

1. Fuquay, J.W. Heat Stress as it Affects Animal Production. J. Anim. Sci. 1981, 52, 164. [CrossRef]

2. Morrison, S.R. Ruminant Heat Stress: Effect on Production and Means of Alleviation. J. Anim. Sci. 1983, 57, 1594-1600. [CrossRef] [PubMed]

3. Gabler, N.K.; Pearce, S.C. The impact of heat stress on intestinal function and productivity in grow-finish pigs. Anim. Prod. Sci. 2015, 55, 1403-1410. [CrossRef]

4. Naqvi, S.M.K.; Kumar, D.; Paul, R.K.; Sejian, V. Heat Stress Impact on Livestock Production. In Environmental Stresses and Livestock Reproduction, 3.; Daramola, J.O., Abioja, M.O., Onagbesan, O.M., Eds.; Springer: New York, NY, USA, 2012; Volume 3, pp. 53-73.

5. St-Pierre, N.R.; Cobanov, B.; Schnitkey, G. Economic Losses from Heat Stress by US Livestock Industries. J. Dairy Sci. 2003, 86, E52-E77. [CrossRef]

6. West, J.W. Effects of Heat Stress on Production in Dairy Cattle. J. Dairy Sci. 2003, 86, 2131-2144. [CrossRef]

7. Baumgard, L.H.; Rhoads, R.P., Jr. Effects of heat stress on postabsorptive metabolism and energetics. Annu. Rev. Anim. Biosci. 2013, 1, 311-337. [CrossRef] [PubMed]

8. Intergovernmental Panel on Climate Change. Climate Change 2013: The Physical Science Basis; Cambridge University Press: Cambridge, UK, 2013.

9. Karimaian, A.; Majidinia, M.; Baghi, H.B.; Yousefi, B. The crosstalk between Wnt/b-catenin signaling pathway with DNA damage response and oxidative stress: Implications in cancer therapy. DNA Repair 2017, 51, 14-19. [CrossRef] [PubMed]

10. Dominick, G.; Bowman, J.; Li, X.; Miller, R.A.; Garcia, G.G. mTOR regulates the expression of DNA damage response enzymes in long-lived Snell dwarf, GHRKO, and PAPPA-KO mice. Aging Cell 2017, 16, 52-60. [CrossRef] [PubMed]

11. Lamming, D.W.; Ye, L.; Katajisto, P.; Goncalves, M.D.; Saitoh, M.; Stevens, D.M.; Ahima, R.S. Rapamycin-induced insulin resistance is mediated by mTORC2 loss and uncoupled from longevity. Science 2012, 335, 1638-1643. [CrossRef]

12. Reiter, A.K.; Anthony, T.G.; Anthony, J.C.; Jefferson, L.S.; Kimball, S.R. The mTOR signaling pathway mediates control of ribosomal protein mRNA translation in rat liver. Int. J. Biochem. Cell Biol. 2004, 36, 2169-2179. [CrossRef]

13. Jirimutu, W.Z.; Ding, G.H.; Chen, G.L.; Sun, Y.M.; Sun, Z.H. Bactrian Camels Genome, S. Genome sequences of wild and domestic bactrian camels. Nat. Commun. 2012, 3, 1202. [PubMed]

14. Taniguchi, C.M.; Emanuelli, B.; Kahn, C.R. Critical nodes in signalling pathways: Insights into insulin action. Nat. Rev. Mol. Cell Biol. 2006, 7, 85-96. [CrossRef] [PubMed]

15. Chen, N.; Fu, W.; Zhao, J.; Shen, J.; Chen, Q.; Zheng, Z.; Chen, H.; Sonstegard, T.S.; Lei, C.; Jiang, Y. The Bovine Genome Variation Database (BGVD): Integrated Web-database for Bovine Sequencing Variations and Selective Signatures. 2019. Available online: https://www.biorxiv.org/content/10.1101/802223v1 (accessed on 13 October 2019).

16. Zhang, Y. Animal Genetic Resources in China - Bovines (in Chinese); China Agriculture Press: Beijing, China, 2011.

17. Qiu, H.; Qing, Z.R.; Chen, Y.C.; Wang, D.A. Bovine Breeds in China; Shanghai Scientific and Technical Publishers: Shanghai, China, 1988. 
18. Xia, X.; Yao, Y.; Li, C.; Zhang, F.; Qu, K.; Chen, H.; Lei, C. Genetic diversity of Chinese cattle revealed by Y-SNP and Y-STR markers. Anim. Genet. 2019, 50, 64-69. [CrossRef] [PubMed]

19. Sambrook, J.; Fritsch, E.F.; Maniatis, T. Molecular cloning: A Laboratory Manual; Cold Spring Harbor Laboratory Press: Cold Spring Harbor, NY, USA, 1989.

20. Hansen, P. Physiological and cellular adaptations of zebu cattle to thermal stress. Anim. Reprod. Sci. 2004, 82, 349-360. [CrossRef]

21. Zeng, L.; Chen, N.; Ning, Q.; Lei, C. PRLH and SOD1 gene variations associated with heat tolerance in Chinese cattle. Anim. Genet. 2018, 49, 447-451. [CrossRef]

22. Zeng, L.; Cao, Y.; Wu, Z.; Huang, M.; Zhang, G.; Lei, C. A Missense Mutation of the HSPB7 Gene Associated with Heat Tolerance in Chinese Indicine Cattle. Animals. 2019, 9, 554. [CrossRef]

23. Yang, R.-C.; Yeh, F.C. Multilocus structure in Pinus-contorta Dougl. Theor. Appl. Genet. 1993, 87, 568-576. [CrossRef]

24. Nei, M.; Roychoudhury, A.K. Sampling variances of heterozygosity and genetic distance. Genetics 1974, 76, 379-390.

25. Yeh, F.C. POPGENE (version 1.3. 1). Microsoft Window-Bases Freeware for Population Genetic Analysis.

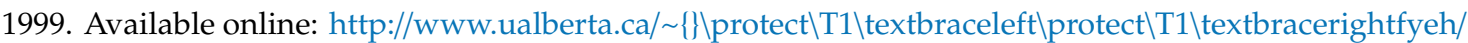
(accessed on 19 June 2019).

26. Botstein, D.; White, R.L.; Skolnick, M.; Davis, R.W. Construction of a genetic linkage map in man using restriction fragment length polymorphisms. Am. J. Hum. Genet. 1980, 32, 314-331.

27. McDowell, R.E.; Hooven, N.W.; Adcamoens, J.K. Effects of climate on performance of Holsteins in first lactation. J. Dairy Sci. 1976, 59, 965-971. [CrossRef]

28. Cun, W.T.; Yu, X.; Liu, W.J.; Zhang, H.; Shi, L.; Xing, W.T.; Cheng, L.M.; Huang, X.X.; Ma, X.Y. Study on Genetic Diversity and Genetic Differentiation of 13 Sheep Populations in Xinjiang Uygur Autonomous Region. Acta Ecol. Anim. Domastici. 2011, 32, 13-19.

29. Becker, J.A.; Stewart, L.K. Heat-related illness. Am. Fam. Physician 2011, 83, 1325-1330. [PubMed]

30. Bouchama, A.; Knochel, J.P. Heat stroke. N. Engl. J. Med. 2002, 346, 1978-1988. [CrossRef] [PubMed]

31. Epstein, Y.; Roberts, W.O. The pathopysiology of heat stroke: An integrative view of the final common pathway. Scand J. Med. Sci. Sports 2011, 21, 742-748. [CrossRef] [PubMed]

32. Leon, L.R.; Helwig, B.G. Heat stroke: Role of the systemic inflammatory response. J. Appl. Physiol. Respir. Environ. Exerc. Physiol. 2010, 109, 1980-1988. [CrossRef] [PubMed]

33. Leon, L.R.; Helwig, B.G. Role of endotoxin and cytokines in the systemic inflammatory response to heat injury. Front. Biosci. 2010, 2, 916-938. [CrossRef]

34. Lei, C.Z.; Chen, H.; Zhang, H.C.; Cai, X.; Liu, R.Y.; Luo, L.Y.; Wang, C.F.; Zhang, W.; Ge, Q.L.; Zhang, R.F.; et al. Origin and phylogeographical structure of Chinese cattle. Anim. Genet. 2010, 37, 579-582. [CrossRef]

35. Xia, X.; Qu, K.; Zhang, G.; Jia, Y.; Ma, Z.; Zhao, X.; Lei, C. Comprehensive analysis of the mitochondrial DNA diversity in Chinese cattle. Anim. Genet. 2019, 50, 70-73. [CrossRef]

(C) 2019 by the authors. Licensee MDPI, Basel, Switzerland. This article is an open access article distributed under the terms and conditions of the Creative Commons Attribution (CC BY) license (http://creativecommons.org/licenses/by/4.0/). 